\title{
NATURAL GAS TRANSPORT ${ }^{1}$
}

\author{
Tomás CorreA* \\ NELSON OSORIO**
}

\begin{abstract}
Alostract
This paper reviews the present and future on natural gas transportation options, from oil and gas fields to markets, including liquefied natural gas, gas pipeline, compressed natural gas, natural gas hydrates, and gas to liquids and the perspectives of using them in Colombia, since this is the main fuel alternative to supply the world in at least the next 50 years.
\end{abstract}

\section{Key words}

Gas transport, Pipeline, LNG, CNG, NGH, GTL

\section{Resumen}

Este artículo explora el presente y futuro de las opciones de transporte del gas natural, desde los yacimientos de gas asociado o gas seco hasta los mercados, incluyendo gas natural licuado, gasoductos, gas natural comprimido, hidratos de gas natural y conversión de gas a líquidos, además de las perspectivas de uso en Colombia ya que este

1 This is an exploratory study of natural gas transport worldwide and perspectives in Colombia.

* Mechanical Engineer of Universidad Nacional de Colombia, Medellin. Master of natural gas engineer and management, Oklahoma University US. He is currently a professor at the Instituto Tecnológico Metropolitano (ITM). tomascorrea@itm. edu.co

** Petroleum Engineer of Universidad Nacional de Colombia, Medellin. Master of natural gas engineer and management, Oklahoma University US. He is currently an engineer of SPT group in Houston US. email to: nelson.f.osorio@gmail.com

Fecha de recepción: 27 de marzo de 2009

Fecha de aceptación: 11 de mayo de 2009 
es la principal alternativa después del petróleo como fuente de energía en el mundo en al menos los próximos 50 años.

\section{Palabras claves}

Transporte de gas natural, gasoductos, gas natural licuado, gas natural comprimido, gas para líquidos, hidratos de gas natural. 


\section{INTRODUCTION}

The current proved reserves of natural gas worldwide are $6,253 \mathrm{Tcf}$ (BP, 2008). This is very large considering the current annual consumption of about 105Tcf (Mariongiu, 2008), amount enough to supply at least the next 56 years (Lochner, 2008, Correa, 2008). Those reserves are mainly in Russia, Iran and Qatar, far away from the consumption regions. $40 \%$ of those proved reserves are considered stranded gas which implies hard conditions to produce and large distance to transport to the end user, sometimes located offshore and short size that are not viable to monetize using traditional transport means like pipeline or LNG (Rajnauth, 2008).

Natural gas transportation is more difficult than other common forms of energy, such as oil or coal, because the energy density of natural gas is low. For instance, an equal volume of the three fuels; oil, coal and natural gas at standard temperature and pressure have different energy content: oil is approximately 1,000 times greater than natural gas and coal is 500 times greater than natural gas as shown on table 1 .

TABLE 1. ENERGY DENSITY FOR DIFFERENT COMBUSTIBLES AND TRANSPORT MEAN (MARTINEZ, 2007)

\begin{tabular}{cccc}
\hline \multicolumn{4}{c}{ Energy Density } \\
\hline Natural Gas & $1000 \mathrm{BTU} / \mathrm{scf}$ & Gas Hydrates & $200,000 \mathrm{BTU} / \mathrm{scf}$ \\
\hline Oil & $1,000,000 \mathrm{BTU} / \mathrm{scf}$ & $\mathrm{CNG}$ & $300,000 \mathrm{BTU} / \mathrm{scf}$ \\
\hline Coal & $500,000 \mathrm{BTU} / \mathrm{scf}$ & $\mathrm{LNG}$ & $600,000 \mathrm{BTU} / \mathrm{scf}$ \\
\hline Pipeline & $100,000 \mathrm{BTU} / \mathrm{scf}$ & & \\
\hline
\end{tabular}

This large difference in energy density, compared with natural gas, highlights two major transport problems for natural gas. First, a relatively high pressure or low temperature is required to increase the gas density and raise the energy content per unit volume and second, large quantities of natural gas cannot be stored in relatively simple and inexpensive aboveground facilities 
similar to those used for liquid-petroleum products(Kidnay, 2006); nevertheless, in many parts of the world, massive reserves of gas exist with no apparent market for the fuel (stranded gas) or short reserves are not viable to monetize under the transport means today; for such reserves, there are different options to monetize natural gas reserves as shown in table 2. Pipeline and LNG are the most used and developed technologies while $\mathrm{CNG}, \mathrm{NGH}$, and GTL are in development. Although there are a few GTL plants worldwide, the technologies still need more developments to reduce capital cost and improve the efficiency. CNG and NGH are the means that could be used in the near future.

Table 2. Reserves Required for gas transportation projects (Rajnauth, 2008)

\begin{tabular}{cccc}
\hline Transport & Reserves required & Transport & Reserves required \\
\hline Pipeline & Depend on distance & GTL & 500Bcf \\
\hline LNG & 1-3Tcf & NGH & 400Bcf \\
\hline GTW & 10bcf-1Tcf & CNG & 300Bcf \\
\hline
\end{tabular}

The first option to transport gas is using long onshore or offshore pipelines to bring the gas to the world consumption centers; however, because of politics issues sometimes is not reliable to transport by this mean, especially when the pipeline goes through two o more countries such as Russia and European countries, Peru and Bolivia in south America, so other transport alternatives should be considered, usually the ocean mainly. The second alternative is to liquefy the gas by cooling it until $-160^{\circ} \mathrm{C}$ and shipping for long distances (LNG); nevertheless, it is capital intense and requires large size of reserves. Other alternative is converting gas into a transportable commodity, such as diesels, Methanol, and Ammonia, at or near the gas source (GTL). There are other alternatives on experimentation such as compressing natural gas to pressures up to 3600psi (CNG) and shipping to consumption centers and gas hydrates (NGH) which consist in storing the gas in water molecules. All of them will be briefly discussed along this paper. The latter two technologies are in the research and development stage and, 
although the potential of these options has been explored in the past decade, no commercial projects exploiting them have been done (Wood, 2008). Figure 1 shows efficient options to monetize gas taking into account distances and volumes; it could be noticed that for short distances below $2000 \mathrm{~km}$ pipeline and CNG systems are better options while for long distances above $2000 \mathrm{~km}$ GTL and LNG are better than the others.

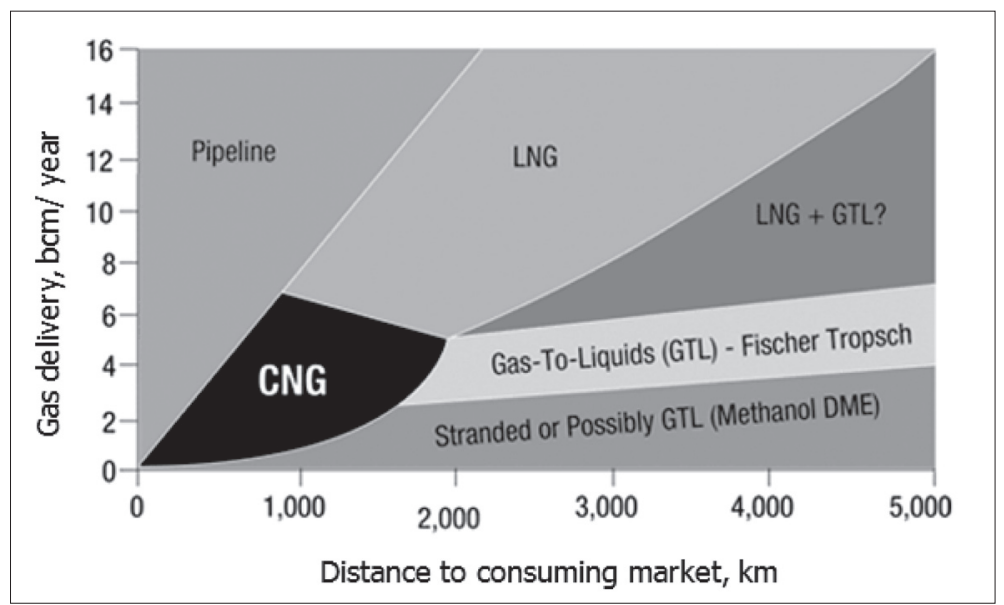

Figure 1. Efficient Options to Monetize Natural Gas

(MARONGIU, 2008)

In Colombia the most important transport mean is pipeline, the most representative trunk line comes from Chuchupa - Ballenas in the north of the country to the Atlantic coast and Andina region. There are some states like Huila in which natural gas is transported by cylinders on trucks for short distances at a pressure up to 3500 psi, it has been a successful mean for unconnected regions from the national gas pipeline grid (CREG, 2001) and Antioquia in which natural gas is transported by containers on trucks among metropolitan area and close cities like La Ceja because of pipeline infrastructure is not still profitable. 


\section{Definitions}

LNG: liquefied natural gas

CNG: compress natural gas

NGH: natural gas hydrate

ANG: Adsorption natural gas

Scf: $\quad$ standard cubic feet

BTU: British thermal units

GTL: gas to wire

Tcf: tera cubic feet

MMscf: millions standard cubic feet

MMBTU: millions of BTU

Bcf: billion cubic feet

b/d: barrels per day

\section{Pipeline}

The growth of natural gas transport by pipeline has led to the establishment of a large network of pipelines throughout the world, $70 \%$ of the gas worldwide is transported by this mean (Wang, 2008). The total length of the world's pipeline is about twice the length used to transport crude oil, and is more than one million kilometers (Rojey, 1997). It amounts to a total length of $450,000 \mathrm{~km}$ in Europe including Russia and 480,000km in the United States (NPC, 2003). The larger and longer lines are normally built with diameters of $76 \mathrm{~cm}$ or more; being the completion of the Cross island Pipeline (CIP) in Trinidad one of the largest diameters pipeline $(143 \mathrm{~cm})$ in the world(Rajnauth, 2008). In general terms, natural gas pipeline could be classified in three categories depending of purpose: Gathering System, a network around the wells to transport the gas to the pretreatment facilities for processing. Transporting pipelines, long pipelines with large diameters, high 
pressures (145-1500psi or up to 2500psi for gas storing), crossing through the cities, countries, even continents using compressor stations which are between 100 and 400km(Hirschhausen, 2007). Distribution Pipelines, several interconnected pipes with small diameters used to take the products to the final consumer.

Economics. Despite their simplicity, pipelines are highly capital intensive. The capital cost of a pipeline depends upon factors such as pipe diameter, distance, terrain, onshore or off shore, and the amount of compression required. In general terms, the cost associated to a pipeline project is between $\$ 600,000$ dollars and $\$ 4$ million dollars per kilometer (Thomas, 2003) being offshore pipelines assumed to be $50 \%$ more expensive to build than onshore pipelines (Lochner, 2008). In some countries, like Australia and Russia, pipelines can be laid over vast distances at a low cost; this is due to the low disturbance, low right-of-way (ROW) charges and relatively accessible terrain. In highly urbanized societies, such ROW charges can add considerably to the cost of the pipeline construction. The expenditures include costs for road, highway, and railroad crossings, stream and river crossings (between 10 and 15\% of the total project costs)(Menon, 2005); in addition, provision for compression stations, which are necessary for mass transport over long distances, can contribute $40 \%$ to the final installed capital cost. Once the pipeline, compressor stations and ancillary facilities are constructed and the pipeline is put into operation, there will be annual operating costs over the useful life of the pipeline, which might be 30 to 40 years or more. These annual costs consist of the following major categories: Compressor station maintenance, fuel or electrical energy cost and compressor station equipment supplies.

\section{Colombia natural gas pipeline}

In Colombia gas transport system is basically by pipeline and the grid accounts with approximately 3,850 kilometers of long pipelines (UPME, 2006), to move around 750 MMscfd. The three main lines are shown in figure 2 and future expansion of the pipe- 
line network is expected in the future; however, the growing of gas pipeline system depend on increases on the demand and transport companies carriage contracts; it means that when the consumption levels reach attractive volume to investors, they would evaluate and eventually invest in a new pipeline system but it could be very risky to satisfy demand increases in short times; nevertheless, on the plan 2006-2025 the Colombian government propose to develop some regulations that allow to assure future expansions in order to satisfy the demand opportunely(UPME, 2007).

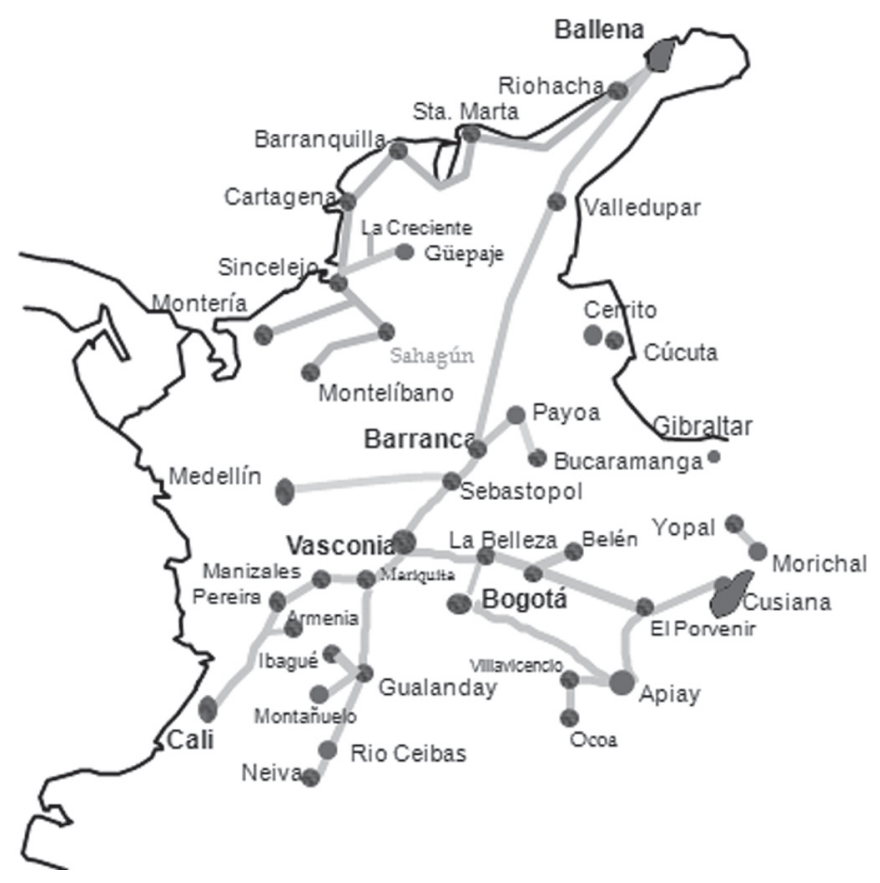

Figure 2. Colombian natural gas pipeline System (Gutierrez, 2008)

On the other hand there is an agreement between Colombian and Venezuela governments to export gas by pipeline from Colombia to Venezuela for 4 years at the volumes shown in table 3. After that, Venezuela will export gas to Colombia from 2016 to 2027 around 150MMscfd. 
Table 3. Gas volumes to transport between Colombia and Venezuela (GUTIÉRREZ, 2008)

\begin{tabular}{cccccc}
\hline Country & $\begin{array}{c}\text { Colombia to } \\
\text { Venezuela }\end{array}$ & $\begin{array}{c}\text { Colombia to } \\
\text { Venezuela }\end{array}$ & $\begin{array}{c}\text { Colombia to } \\
\text { Venezuela }\end{array}$ & $\begin{array}{c}\text { Colombia to } \\
\text { Venezuela }\end{array}$ & $\begin{array}{c}\text { Venezuela } \\
\text { to Colombia }\end{array}$ \\
\hline Year & 2012 & 2013 & 2014 & 2015 & $2016-2017$ \\
\hline MMscfd & 39 & 85 & 127 & 144 & $\sim 150$ \\
\hline
\end{tabular}

\section{Liquified Natural Gas (LNG)}

LNG is other alternative to transport natural gas; it is transported at $-160^{\circ} \mathrm{C}$ temperature and ambient pressure and it has a volume of $1 / 600$ of the gas at standard conditions. LNG can be transported on land (small scale on experimentation) or by sea from remote regions to consumption cities; $30 \%$ of natural gas worldwide is transported as LNG (Wang, 2008). LNG project requires large scale development of a gas field (more than $1 \mathrm{Tcf}$ of reserves), delivering typically $1 \mathrm{Bcf} / \mathrm{d}$. This method is the most economic option for transporting gas over long distances (above $4000 \mathrm{~km}$ ) when compared with pipeline projects (Economides, 2006). LNG involves four different procedures; gas cleaning, liquefaction, shipping and regasification. Liquefaction is the most expensive procedure followed by shipping and regasification.

Gas cleaning: LNG is stricter when compared with the gas pipeline transport; natural gas coming from reservoirs is treated as follows: - acid gases are removed, in the early stages, to avoid $\mathrm{CO}_{2}$ and $\mathrm{H}_{2} \mathrm{~S}$ freezing of the liquefaction process. - The water is removed from the gas to avoid hydrates formation in pipelines and vessels. - Mercury is removed, since the presence of mercury causes corrosion problems in the aluminum heat exchangers used in the liquefaction process.

Liquefaction: Liquefaction technology consist in condensing natural gas 600 times while reaching a temperature of $-160^{\circ} \mathrm{C}$.There are several different engineering approaches to this process that differentiate the proprietary technologies; the cascade process, the mixed refrigerant process, and the expander cycle process are the 
most used worldwide. The key differences among these processes are their use of different refrigerants, exchangers and number of refrigeration systems. Shipping: there are two main types of LNG tankers, Moss type and Membrane type. Moss tanker uses spherical tanks and Membrane uses tanks with the same shape of the ship hulls. These tank shape differences make membrane tankers smaller and consequently less space to be occupied to pass through inter-oceanic canal restrictions. In terms of capacity the most common size today corresponds to the range of the 135,000 $-145,000 \mathrm{~m}^{3}$, but the world largest vessel is under construction and its capacity is $266,000 \mathrm{~m}^{3}$. Nowadays, there are 196 ships working, 134 under construction, two firm options and 19 futures tenders (UPME, 2007). Regasification: The regasification or vaporization is accomplished by three means; Addition of heat from ambient air, ambient water, or integral fired/remote-fired vaporizers. The cost of the regasification system generally represents only a small fraction of the cost of the storage plant around $11 \%$ as showed in figure 3 . There are currently approximately 49 existing regasification terminals and 28 proposed terminals worldwide (Fernandez, 2006).

Economics: The most important investment consists of LNG liquefaction trains. LNG costs share is shown in figure 3; the liquefaction plant is around 50 percent of the total cost, it includes compressors, exchangers, refrigerants, while shipping involves the cost of the vessels basically and offloading involve regasification plants and storages. Close to the $11 \%$ of the gas is lost in the liquefaction process.

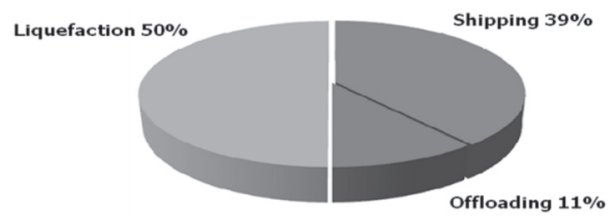

Figure 3. Capital cost allocation for LNG projects (Economides, 2006)

Table 4 shows a typical investment for LNG project. 
TABle 4. BREAKDOWN OF LNG costs (RAJnAUth, 2008)

\begin{tabular}{cc}
\hline & Average costs US billion \\
\hline Gas gathering & $1-1.5$ \\
\hline Liquefaction(1 train) & $1-1.5$ \\
\hline Ships(5) @\$180million & 0.9 \\
\hline Regasification & 0.5 \\
\hline Total & $3.4-4.4$ \\
\hline
\end{tabular}

\section{Colombia LNG}

In South America, Peru is the only country which has a LNG plant under construction and it is expected to start up in 2010; Venezuela and Brazil are other countries that could be interested in LNG but until now there is not project executed. On the other hand, in Colombia there are studies which show three different potential reserves in the Atlantic coast, offshore at deep water and the possibilities to develop LNG as a feasible way to monetize such reserves (Tovar, 2007).

\section{Compressed Natural Gas (CNG)}

There are some circumstances, such as small to medium markets, short distances, subsea topography, short deepwater gas reserves, in which LNG and pipeline transportation technology are not feasible in economic terms, then CNG could be an alternative to monetize the stranded gas. In a CNG project, standard compression facilities are used to compress gas up to $3600 \mathrm{psig}$, and this gas is transported in specially pressured vessels on distances up to $2500 \mathrm{~km}$.

Over the years the only CNG transport service economically feasible has been truck based systems for short distances on land. The maritime CNG concept is similar to this, but on a larger scale, using special containers aboard ships to store and deliver the compressed gas. This option is still considered an experimental alternative; even though, since the 1960's some companies have been trying to transport natural gas in this way. The initial design 
for Columbia Gas, back in the 1960's, was known as the "bottle ship" (Rynn, 2007). But those efforts to commercialize marine CNG transport were deemed to be uneconomic due to high cost of steel alloy (White, 2005. Rynn, 2007). During the last decade there has been a renewed interest in transporting natural gas to monetize stranded gas in regions where the subsea pipeline has usually been the chosen method for distances up to $2500 \mathrm{~km}$ or less (White, 2005), those places like the Colombian and Venezuelan coasts in South America, Sakhalin Island in Russia, Malaysia and Mediterranean sea are among the candidates to monetize gas by CNG as shown in figure 4.

Some circumstances make the CNG economically suitable compared to LNG or pipeline alternatives. In rough and mountainous sea bottom conditions and marginal gas supply with a projected short field life, the economical or technical cost of installing a pipeline may be prohibitive; in the same way, under short size reserves a LNG project could be economically unfeasible because of its high investment cost, then, CNG seems to have its own market niche assured (Rynn, 2005).

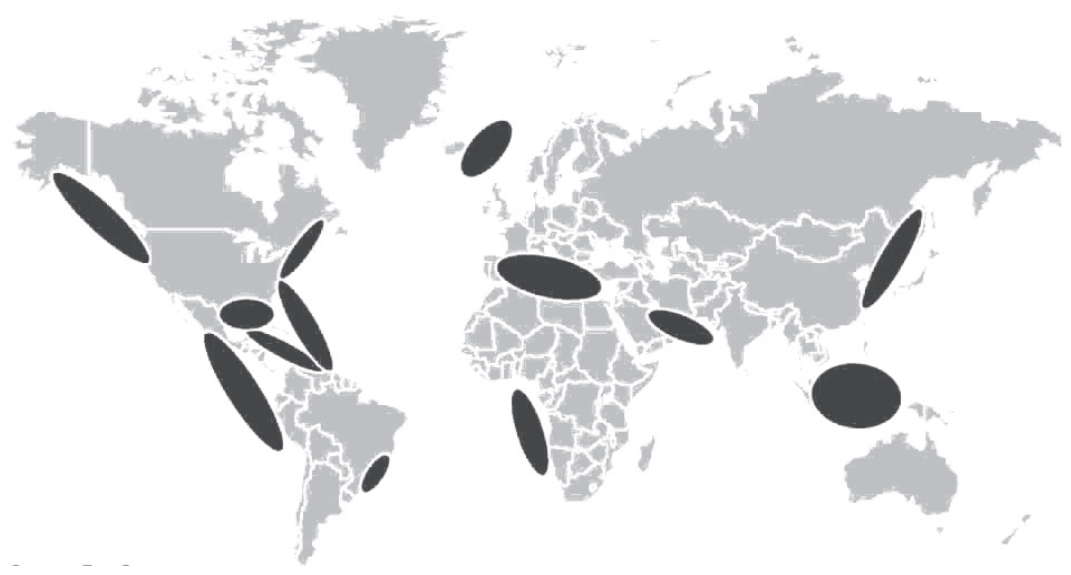

Figure 4. TRade generally limited to about 2500 naUtical miles

(ECONOMIDES, 2006) 
The main advantage for CNG technology is that it is a simple process and lies in the lower cost of gas clean up, compression, loading and offloading facilities, rather than in lower shipping costs relative to LNG. A CNG system would have the advantages of: elimination of the expensive cryogenic plant for the production of LNG, lowering the gas processing costs, because the exhaustive elimination of condensable components would not be required; lower times to loading, offloading and shipping; the no requirement of regasification facilities at the receiving port and the lower energy used to produce CNG (estimated at about one-half of that required for LNG) (Cano, 2005). Main drawbacks of CNG are that transportation and containment technology has not been proved on a commercial scale, resulting in significant uncertainty in the cost of a CNG project. A key factor to overcome this disadvantage is the development of a new containment technology with lighter and stronger storage materials in conjunction with optimized transportation conditions; those changes could decrease the shipping cost and increase the safety in transportation and offloading.

Shipping costs have shown to have a greater influence in CNG project economics; thus, the right shipping technology selection is a must in the project conceptual and design phases. There are several methods of shipping under development and the more representatives are: The Coselle, which comprises around $16 \mathrm{~km}$ of small $6 \mathrm{in}$. diameter pipe coiled around a carousel with a capacity of approximately 3.3 MMscf of natural gas at near ambient temperature and a pressure of 3300psi. A standard bulk carried vessel is used to contain between 108 and 144 coselles, this would transport a volume between 345 and 450MMcfd of gas (Rajnauth, 2008. Seddon, 2006). The Votrans system uses large diameter pipes in an insulated cold storage unit, carrying the gas at low temperatures $\left(-30^{\circ} \mathrm{C}\right)$ allowing lower pressures to be used than the ones required for ambient storage (Cano, 2005). Votrans could transport up to 2Bscf of natural gas by ship (Thomas, 2003), Several studies demonstrate that it would be reduced the amount of steel required for the container if the temperature is kept at lower 
values, for instance, for a lean gas, a Votrans steel container at a containment temperature around $-30^{\circ} \mathrm{C}$ and high pressure, the wall thickness requirement is roughly half of that at high pressure at ambient temperature (White, 2005). The GTM is a light weight composite reinforced pressure vessel that is based upon technology that has been used in CNG vehicle fuel tanks for over 20 years The GTM system is made from a high-strength, low-alloy (HSLA) steel pipe, wrapped with composites. GTMs are approximately $35 \%$ lighter than conventional steel tanks and the vessel can be used to transport natural gas by rail, ship or truck (Cano, 2005).

3.2 Economics: There are no examples of a CNG project on operation at this time, but the cost of shipping would be the major cost component, which would typically be around $80 \%$ to $89 \%$ of the total project cost, as it is shown in figure 5 .

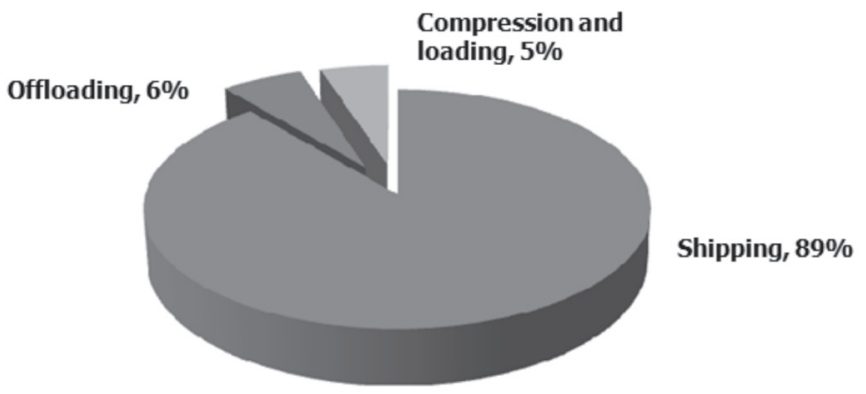

Figure 5. CApital cost allocation for CNG projects (EConomides, 2006)

The shipping capex is directly related with the cost of the materials involved in the design of the ship cargo containment. This cost is function of the storage efficiency, the temperature control, the optimal pressure selection, and the materials selected to build the containers. CNG would be of interest for relatively short distances $(500 \mathrm{~km}$ to $3,000 \mathrm{~km})$, but the distance to market is also a function of the size of reserves and the technology efficiency of the ships ; higher storage efficiency could develop a wider market for the project, reaching points even farther from the source of supply compared to less efficient means. CNG project economics also showed to depend on the market price, for instance, the lower 
the natural gas market price; the shorter the market influence radius the project could cover profitably.

\section{Colombia CNG}

Colombia has a strategic position for the development of a marine CNG project especially in the Guajira North Coast, thanks to the short distances, less than $3000 \mathrm{~km}$, to potential markets in the Caribbean Sea, Central and North America. The future developments from gas fields in the area and the proximity to gas fields and associate gas production from Venezuela give the initial condition to initiate such a project. An preliminary studies about Colombia CNG which will be published later on has demonstrated that with just gas reserves around $1.4 \mathrm{Tcf}$ the $\mathrm{CNG}$ project can be economically attractive even at a market price of $\$ 6 / \mathrm{MMBTU}$

\section{Natural Gas Hydrate}

Natural gas hydrates are crystalline solid compounds formed from water and natural gas molecules. NGH are a subset of the compounds called clathrate. The term "clathrate", from the Greek word khlatron, meaning barrier, indicates crystalline inclusion compounds in which small guest atoms or molecules are physically trapped in host cavities shaped by a three dimensional assembly of hydrogen bonded molecules(Chatti, 2004).

Even NGH transport is still on experimentation, the process of gas delivery as NGH involves three steps, hydrate formation/ production, transportation to the demanding place and dissociation/regasification of the hydrate structure. If NGH is produced synthetically, the first step is generally achieved by mixing gas and water under hydrate formation conditions, it implies temperatures between $1^{\circ} \mathrm{C}$ and $10^{\circ} \mathrm{C}$ and pressures from 1100 to $1450 \mathrm{psi}$ (Thomas, 2003); the result is a water crystalline ice like substance where the natural gas components stabilize the hydrogen bonds within water. Because one of the disadvantages of the gas hydrate is the rate in which gas hydrate is formed, sometimes in order to increase the 
hydrate formation, surfactants can be added to the solution. During the transportation stage, the hydrates are cooled to approximately $-15^{\circ} \mathrm{C}$ at atmospheric pressure to ensure their stabilization during storage in insulated bulk carriers. The dissociation of NGH can be achieved by several methods such as depressurization, thermal stimulation where the hydrates are slowly melted, releasing gas from the resulting water; or thermodynamic inhibitor injection, chemical inhibitors such as methanol or MEG. Even though these studies have shown that storing natural gas in hydrate form is feasible, applications have not progressed beyond the laboratory stage because of complexities of the process, slow hydrate formation rates and costs (Wood, 2008).

Hydrate storage and transportation has the advantage of a lower storage space and low pressures, a good point in safety terms. NGH has an energy density equivalent to a highly compressed gas, $1 \mathrm{~m}^{3}$ of hydrate contains $150-180 \mathrm{~m}^{3}$ of gas per $\mathrm{m}^{3}$ of water, but is less dense than liquefied natural gas (LNG) with a ratio $640 \mathrm{~m}^{3}$, of as per $\mathrm{m}^{3}$ gas.(Sloan, 2008).

\section{Economics}

Surveys of natural gas resources world-wide indicate that about $80 \%$ of the new reserves discoveries will be smaller than the minimum required making LNG projects economical, hence the great interest in NGH and similar new technologies. In the same way, it has been demonstrated when comparing production LNG plant vs. NGH plant producing 10 million metric ton/year (LNG equivalent), that moving the methane through all the necessary phases: hydrate formation, storage and controlled dissociation, the results have an estimated total costs around $75 \%$ of the LNG plant under the same volume conditions for global consumers in a near future (2020-2030). The only demonstration project has been done by Japanese companies; it is a plant which produces as much as 600 kilograms of hydrate per day (Hirschhausen, 2007). 


\section{Colombia}

There is not an ongoing research or development about NGH as a transportation mean in the country. Development of such a technological application requires high investment and the uncertainty tied to its feasibility is high, so, there is not, apparently, a strong reason to think NGH as an option to monetize gas reserves when there is other type of technology available like CNG, LNG or pipeline to develop them.

\section{Gas to LiquidS}

GTL is not a direct gas transportation method but it allows indirectly delivery of the gas produced in the stranded gas zones. This technology generally refers to the chemical conversion of natural gas into more valuable chemical or refinery feedstock such as ammonia or methanol. GTL technology enables cost-effective development of otherwise uneconomical, medium-sized natural gas resources and the production of various sulfur-free, high quality fuels for export or local market use. There are two technologies to produce synthetic liquid hydrocarbons, a direct conversion from gas, and an indirect conversion via synthesis gas (syngas). The direct conversion uses natural gas which contains 85 to 90 percent Methane to convert it directly to liquid hydrocarbon thru an oxidative coupling or thermal coupling; main drawbacks of this technology are the requirements of high reaction energy and the out of control process, for that reason it has been found not to be feasible technically nor economically (Weizhou, 2004). The indirect conversion via syngas is based essentially in three steps, first, the conversion of natural gas to synthesis gas (a mixture of $\mathrm{H}_{2}$ and $\mathrm{CO}$ ) by incomplete combustion, second, the conversion of synthesis gas to synthetic long chain hydrocarbon, which can be achieved via Fischer-Tropsch synthesis, via methanol or dimethyl ether DME and third, upgrading of the synthetic oil to the various final products. 
One advantage of GTL-Fischer Tropsch process is the production of high quality free of sulphur, nitrogen and aromatic compound products which eliminate $\mathrm{NOx}$, SOx and unburned hydrocarbons emissions (Ahmad, 2002). Main drawback of GTL - Fischer Tropsch process is the low overall plant efficiency, which is around $60 \%$, due to the unavoidable heat loss during the conversion process

Economics Several economical drivers influence the development of a GTL project, a high international market price of fuels and petrochemical products produced such as gasoline and methanol could leverage in favor of this technology implementation, also, medium size reserves that cannot support a large LNG plant could support a GTL plant which only requires 25 to $50 \%$ of the gas supplies required for a LNG development (IEA, 2003). GTL processing are highly dependent on plant construction costs, product types and yields, the market prices of the liquids produced and the gas feedstock, and the cost of carbon dioxide emissions due to environmental regulations.

GTL plants are complex and capital-intensive. They require large sites and construction lead times of two-and-a-half to three years. Capital cost is function of location, construction and labor costs. Syngas production accounts for about $30 \%$ and the Fischer-Tropsch synthesis process itself about $15 \%$ of capital costs, with other processing units, power generation and ancillary services making up the rest (IEA, 2003). Around 10 MMBTU of natural gas is required per barrel of liquid produced so, access to low-cost gas feedstock is crucial to the economics of GTL projects. A 75,000-b/d plant would, therefore, cost about $\$ 1.5$ billion dollars (Marin, 2005).

Although there are several large-scale commercial plants currently in operation around the world such as in South Africa (Mossel Bay), Malaysia (Bintulu), Russia (Syntroleum/Yakut), Egypt (Shell/EGCP), Nigeria (Drake Synergy), Algeria (Sonatrach), Iran (Narkanan) and Australia (Shell Australia), much of the growth in GTL production is occurring in the Middle East, centered especially in Qatar which has been the place of development of more 
than nine GTL plants including the construction of the largest plant worldwide with a capacity of $140,000 \mathrm{~b} / \mathrm{d}$ of liquids.(IEA, 2003).

\section{Colombia GTL}

GTL has a growing interest in the country; several attempts to implement the technology has been proposed to monetize associated gas from reservoirs such as Cusiana ad Cupiagua, building a 84,000 $\mathrm{b} / \mathrm{d}$ plant, but they have been retracted because of the soaring high cost of installation and the lack of governmental support. Feasibility studies have been done in order to assess the potential for liquid products from Coal rather than from natural gas, since the coal reserves are quite significant, such studies demonstrated that coal to liquids is feasible and competitive to the crude oil(Anh, 2007), but even though those results, the environmental issues continue being a concern. High investment cost, long term development project and the low significant reserves make the GTL, up to now, a discouraging alternative to monetize gas in Colombia.

\section{General Considerations}

1. There is a need for non-pipeline technologies that can capture stranded gas and transport it to market. CNG, NGH technologies are being developed for this purpose and are increasingly recognized as attractive alternatives.

2. Gas transporting infrastructure development in Colombia will depend on the new legislations to facilitate the construction of new gas pipelines by private companies.

3. The use of different methods to transport gas to large scale in Colombia will depend on the exploration in Atlantic coasts, the size of the reserves and the future scenarios worldwide.

4. CNG and LNG could be better options to export gas from Colombia to Central America and North America in an optimistic scenario. 
5. Natural gas transportation (large scale) options to Colombia, in the near future, should be discussed and proposed in order to assure the natural gas supply in the next decades taking into account and an eventual or pessimistic scenario in which the country has to import natural gas.

6. Future studies should be done to analyze different natural gas transports to small scale in which pipeline infrastructure is not affordable; CNG, ANG or LNG could be alternatives to consider.

\section{References}

Ahmad I. (2002). Gas to liquid. Technology. New Energy technology for the third millennium. SPE Paper 78573. Abu Dhabi 2002.

ANH. UPME. UTCTL. (2007). Análisis y Evaluación Técnica y Económica de la producción de combustible líquido a partir del carbón para el caso Colombiano.

BP. (2008). Statistical Review of World Energy. London: BP p.l.c., 2008. P.22.

Cano G., Stephen G. (2005). CNG marine transports a gas transportation company perspective. OTC 17171 , this paper was selected for presentation at the offshore Technology Conference held in Houston May 5. Offshore technology Conference.

Chatti I., Delahaye A., Fournaison L., Petitet J. (2004). Benefits and drawbacks of clathrate Hydrates: a review of their areas of interest. Energy conversion and management. 46(2005) 1333-1343.

Correa T., Castrillon E. (2008). Almacenamiento de gas natural. Revista Tecnológicas, Instituto Tecnológico Metropolitano, ITM. Número 21. Diciembre. Segunda época. pp 145-167.

CREG. (2001). Definición de costos en el transporte de gas natural comprimido para el abastecimiento de poblaciones sin gasoductos. COINOR LTDA.

Economides M., Sun K., Subero G. (2006). Compressed Natural Gas (CNG): An Alternative to Liquefied Natural Gas (LNG) Journal SPE Production \& Operations Volume 21, Number 2. SPE 92047. Society of Petroleum Engineers. pp. 318-324. 
Fernández J. (2006). Transporte marítimo de la cadena de gas, economía de la cadena de gas. Repsol, gas natural LNG.

Gudmundsson J., Graff O., Kvaerner A. (2003). Hydrate non-pipeline Technology for transport of natural gas. $22^{\text {nd }}$ World Gas Conference Tokyo.

Gutierrez J. (2008). Perspectivas Gas Natural. XI Asamblea y congreso anual de Naturgas.

Hirschhausen C., Neumann A., Ruster S. (2007). Competition in natural gas transportation? Technical and economic fundamentals and an application to Germany. Globalization of natural Gas Markets working Papers. German Institute for economic Research. Berlin.

International Energy Agency, IEA. (2003). World Energy investment Outlook. pp. 116-118.

Kidnay A., Parrish W. (2006). Fundamentals of Natural Gas Processing. Taylor \& Francis Group. pp. 251-263.

Lochner S., Bothe D. (2008). The development of natural gas supply costs to Europe, the Unites States and Japan in a globalization gas marketmodel based analysis until 2030. Energy policy 37(2009) 1518-1528. September.

Marin H. (2005). Technical and Economical study of a GTL Plant in Venezuela. The University of Oklahoma.

Martínez I. (2007). Plantas de licuación de gas, Curso de Economía de la cadena del gas V edición. Dirección de tecnología de gas. Repsol YPF. V Edición, Octubre.

Marongiu M., Wang X., Economides M. (2008). The Economics of Compress Natural Gas Sea Transport. This paper was prepared for presentation at the 2008 SPE Russian oil \& Gas technical conference and exhibition held in Moscow. SPE 115310.

Menon S. (2005). Gas Pipeline Hydraulics. CRC Taylor \& Francis Group. pp. 330-333.

NPC. (2003). Balancing Natural Gas Policy, Fueling the demands of a growing Economy. National Public Council pp. 235-237.

Rajnauth J., Ayeni K., Barufet M. (2008). Gas Transportation: Present and Future. SPE 114935. This paper was prepared for presentation at the CIPIC/SPE Gas Technology Symposium 2008 Joint conference held in Calgary, Alberta, Canada, 16-19 June 2008.

Rojey A., Jaffret C. (1997). Natural Gas Production Processing Transport. Editions Technip. French Institute of Petroleum. pp. 309-315. 
Rynn P., Patel H. y Gaughan J. (2005). ABS Development of a guide for Compressed Natural Gas Carriers. International Offshore and Polar Engineering Conference Seoul Korea. June 19-24

Rynn P., Patel H. y Serratella C. (2007). ABS Development of a guide for Compressed Natural Gas. This paper was prepared for presentation at the 2007 offshore Technology conference held in Houston Texas, USA. 30 April.

Seddon D. (2006). Gas Usage \& Value. The technology and economics of Natural Gas Use in the Process Industries. Pen Well Corporation. pp. 260-261.

Sloan D. (2008). Clathrate hydrates of natural gases. Chemical Industries V 119. CRC press USA.

Thomas S., Dawe R. (2003). Review or ways to transport natural gas energy from countries which do not need the gas domestic use. Petroleum Engineering Unit. Department of Chemical Engineering, the University of West Indies, St. Augustine, Trinidad and Tobago. Energy 28(2003) 1461-1477.

Tovar E. (2007). LNG as alternative to monetize potential reserves to be discovered at the Colombian Caribbean deep water. Thesis of Natural Gas Energy and Management.

UPME. (2006). The natural gas chain in Colombia. Unidad de planeación minero energética. Ministerio de Minas y energía. pp. 50-66.

UPME. (2007). Plan Energético Nacional 2006-2025. Propuesta de objetivos y estrategias Páginas 146 -147.

Wang X., Marongiu M. (2008). The Potential of compressed Natural Gas transport in Asia. IPTC 12078. This paper was selected for presentation at the international petroleum technology conference held in Kuala Lumpur, Malaysia, December.

White C., Dunlop J. (2005). Votrans CNG provides transport solutions for deep water associated gas. OTC 17492. This paper was prepared for presentation at the 2005 offshore Technology Conference held in Houston May 5. Offshore technology Conference.

White C., Britton P., Naoki Y, (2005). Technical advancements Votrans large scale CNG marine transport. Proceeding of the fifteenth international offshore and polar engineering conference Seoul Korea. June.

Wood D., Mokhatab S. (2008). Gas monetization technologies remain tantalizingly on the brink. World oil magazine. 